\title{
The Effect of Biostimulators on the Tastiness and Darkening of the Pulp of Raw and Cooked Potato Tubers
}

\author{
Iwona Mystkowska1* , Alicja Baranowska', Krystyna Zarzecka², \\ Marek Gugała², Anna Sikorska ${ }^{3}$
}

1 Department of Environment Sciences, Pope John Paul II State School of Higher Education. Sidorska 95/97, 21-500 Biała Podlaska, Poland

2 Department of Agrotechnology, Faculty of Natural Sciences, Siedlce University of Natural Sciences and Humanities, B. Prusa 14, 08-110 Siedlce, Poland

3 Department of Agriculture, The State Higher School of Vocational Education in Ciechanów Narutowicza 9, 06-400 Ciechanów, Poland

* Corresponding author's e-mail: imystkowska@op.pl

\begin{abstract}
Field experiments were carried out in 2015-2017 with the use of bio-stimulators on an individual farm in Międzyrzec Podlaski. The experiment was based on a random split-plot method. The influence of two first factors was examined. The primary factor included three varieties of edible potato: Honorata, Jelly, Tajfun, and the secondary factor involved five ways of using bio-stimulators: Kelpak SL, Titanit, Green Ok, Brunatne Bio Złoto Cytokinin. The aim of the study was to evaluate the effect of bio-stimulators on the tastiness and darkening of the pulp of raw and cooked tubers after 10 minutes. The effectiveness of the application of individual bio-stimulators in the cultivation of edible potato varieties: Honorata, Jelly and Tajfun was compared with the control object (without using bio-stimulators) sprayed with water. The methods of using bio-stimulators did not change the tastiness and darkening of the pulp of raw tubers, but they had a significant impact on the darkening of the pulp of the cooked tubers. The raw and cooked pulp of the Honorata variety darkened the least, and the Jelly variety turned out to be the tastiest, scoring 8.0 points on a scale of $1-9$ compared to the remaining varieties.
\end{abstract}

Keywords: potato, varieties, biostimulators, tastiness, darkening of the pulp

\section{INTRODUCTION}

The main goal of edible potato producers is to obtain a high yield of good quality [Nowacki 2006, Zarzecka 2006]. The concept of potato tubers quality is very broad and includes such features as: good reproductive properties, resistance to diseases, low susceptibility to spotty pulp, emptiness and dark spot patches, regular shape of tubers with shallow recesses, storage stability, high nutrient content, especially starch and protein, and good culinary properties (taste, aroma, colour, consistency, low tendency to darken of raw and cooked tubers) [Varis 1970, Grudzińska and Zgórska 2008a]. The afore-mentioned features are influenced by many agrotechnical fac- tors, which are determined by the producer, and environmental factors, while the consumer makes a purchase choice and assesses the culinary value of potato tubers [Gugała et al. 2016, KrochmalMarczak et al. 2016]. The potato intended for consumption and processing for food purposes should be characterized by appropriate features related to the properties of the pulp. The most important qualities of culinary quality include: tastiness, non-darkening of raw and cooked tubers [Chotkowski and Rembeza 2006, Grudzińska and Zgórska 2006a, Stypa 2004].

In order to obtain the best quality of the crop alongside pesticides, a number of qualified preparations are used, referred to as plant development regulators or bio-stimulators [Maciejewski et 
al. 2007]. The task of bio-stimulators is to control and accelerate vital processes, increase the resistance of plants to the stress conditions as well as stimulation of root and leaf development. Due to the way they work, they are safe for people, animals and the environment [Kozak 2009, Słowiński 2004].

The aim of the study was to determine the effect of bio-stimulators on the tastiness and darkening of raw and cooked tubers.

\section{MATERIAL AND METHODS}

Field research was carried out in 2015-2017 on an individual farm in Międzyrzec Podlaski, Biała Podlaska country, Lublin voivodeship. The experiment was established in three replications using the random split-plot method on the soil included in the very good rye complex, class IVA. The first factor were the three medium early varieties of edible potato: Honorata, Jelly and Tajfun, and the second one, five ways of using foliar biostimulators in three dates (the beginning of flowering, in the full flowering and after flowering of the plants (Table 1).

Winter wheat was the forecrop for potato in particular years of research. After harvesting the forecrop, a set of post-harvest crops was made. In autumn of each year preceding planting, natural fertilization was used in the form of manure in the amount of $25.0 \mathrm{t} \cdot \mathrm{ha}^{-1}$ and mineral fertilization with phosphorous-potassium in the amount of $\mathrm{P}-44.0$ $\left(100 \mathrm{P}_{2} \mathrm{O}_{5} \cdot 0.44\right) \mathrm{kg} \cdot \mathrm{ha}^{-1}$ (lubofos for potatoes $7 \%$ ) and $\mathrm{K}-124.5\left(150 \mathrm{~K}_{2} \mathrm{O} \cdot 0.83\right) \mathrm{kg} \cdot \mathrm{ha}^{-1}$ (lubofos for potatoes $25 \%$ ). These fertilizers were plowed with the pre-season plowing. The nitrogen fertilizers were sown in spring in the amount of $\mathrm{N}-100$ $\mathrm{kg} \cdot \mathrm{ha}^{-1}$ (nitro-chalk 27\%) and mixed with the soil using a cultivator. Potatoes were planted manually under the marker at a spacing of $67.5 \times 37 \mathrm{~cm}$, in the third decade of April $(2015,2016,2017)$.
Each plot consisted of five ridges. Cultivation and care treatments were carried out in accordance with the requirements of correct agricultural technology and the methodological assumptions of the experiment. The harvest was performed at full ripeness of tubers, in the first decade of September. The assessment of the consumer value of tubers (pulp colour, tastiness, culinary and utility type, darkening of raw and cooked tubers) was marked according to the EAPR scale (European Association for Potato Research). The evaluation of the darkening of the pulp of raw and cooked tubers and tastiness was made by a four-person team, 8 days after harvesting. The taste rating was performed using a nine-point scale, taking the 9 score as very good, and 1 as very bad. The darkening of the pulp of raw and cooked tubers was determined after 10 minutes after cutting. The assessment was made on the longitudinal section of 10 tubers using colourful Danish tables with a nine-point scale reversed in relation to the table, where 9 means no darkening, and 1 - the strongest darkening [Roztropowicz et al. 1999].

The results of the research were statistically analysed using the analysis of variance. The assessment of significance of differences at the level of $p=0.05$ between the compared averages was determined by means of multiple Tukey intervals. The significance of the sources of variation was tested with F Fischer-Sendecor test. The weather conditions during the research in individual potato growing seasons were varied. The highest average air temperature was recorded in 2016 and it amounted to $15.8^{\circ} \mathrm{C}$, it was higher than the longterm average by $0.8^{\circ} \mathrm{C}$, and the highest number of rainfall was recorded in the growing season of 2017-325.4 mm. The lowest average temperature of 14.6 was noted in 2017, and the lowest amount of precipitation - $200.9 \mathrm{~mm}$ in 2016, lower than the long-term sum by $134.5 \mathrm{~mm}$. The growing season of 2015 proved to be an average air temperature of $15.2^{\circ} \mathrm{C}$, higher by $0.2^{\circ} \mathrm{C}$ from the long-term average and rainfall at the level of $295.1 \mathrm{~mm}$ (Table 2).

Table 1. Methodological data of experiment

\begin{tabular}{|c|l|}
\hline No. & \multicolumn{1}{|c|}{ Objects } \\
\hline 1. & control $^{*}+$ spraying with distilled water \\
\hline 2. & control $^{*}+3 x$ (beginning, fullness and after flowering) foliar Kelpak SL in a dose of $2.0 \mathrm{dm}^{3} / \mathrm{ha}^{-1}$ \\
\hline 3. & control $^{*}+3 \times$ (beginning, fullness and after flowering) foliar Titanit in a dose of $2.0 \mathrm{dm}^{3} / \mathrm{ha}^{-1}$ \\
\hline 4. & control $^{*}+3 \times$ (beginning, fullness and after flowering) foliar Green Ok in a dose of $2.0 \mathrm{dm}^{3} / \mathrm{ha}^{-1}$ \\
\hline 5. & $\begin{array}{l}\text { control }^{*}+3 x \text { (beginning, fullness and after flowering) foliar Brunatne Bio Złoto Cytokinin in a dose of } 2.0 \\
\mathrm{dm}^{3} / \mathrm{ha}^{-1}\end{array}$ \\
\hline
\end{tabular}

* - NPK soil fertilization, only mechanical care. 


\section{RESULTS AND DISCUSSION}

The most important features determining the usefulness of potato varieties for direct consumption and for processing include: tastiness, which should be good and very good (above 6.5 on a scale of 1-9) and darkening of raw tuber pulp (above 6.5 points) and cooked tubers (above 7.5 on a scale of 1-9) [Zgórska and Grudzińska 2010, 2011]. In the conducted studies, the tastiness of tubers depended significantly on the variety, methods of using bio-stimulators and meteorological conditions during potato vegetation. The Jelly variety was the tastiest and it scored 8.0 points on the nine-point scale, while Tajfun was also characterized by good taste, with a value of 7.9 points. The Honorata variety had the worst taste with an average score of 7.7 points. The taste rating developed in the same order as in the Characteristics of the National Register of Potato Varieties [Nowacki 2012], where the tastiness of the Jelly variety was rated 7.5 points, Tajfun 7.0 , and the Honorata variety as 6.7 on a scale from 1-9. In the studies of Wichrowska and Rogozińska [2010], tastiness is a genetically determined trait and depends on the chemical composition of tubers, while the environmental variability is subject to it to a small extent.

No deterioration of the taste of the tubers collected from the objects sprayed with bio-stimula- tors was found in comparison to the control object. The tubers collected in 2015 and 2017 were the tastiest, and those in 2016 were the least tasty, which was characterized by a slight drought. The studies conducted by other authors have shown that the palatability is a feature dependent on the environmental impact [Nowacki 2002]. The studies conducted by Urbanowicz [2010] showed that years of research and experiment variants did not change the taste. The interactions between years and varieties, years and ways of using bio-stimulators, varieties and methods of ways of using bio-stimulators, and years and experiment factors were not proven.

In the conducted studies, the darkening of the raw pulp evaluated after 10 minutes from cutting the tubers was shaped by significant varieties and weather conditions in the growing seasons (Table 4). The pulp of the studied varieties: Honorata, Jelly and Tajfun was similar - on average 8.8 points on a nine-point scale. Darkening of raw tuber pulp is considered by many authors to be a genetic trait [Ciećko et al. 2005, Sawicka et al. 2006, Zarzecka and Gąsiorowska 2000].

There was no significant influence of the ways of using bio-stimulators on the assessed feature of the consumer value. It was observed that a large amount of tubers darkened in 2017, the year which turned out to be the coldest and the most humid, with a hydrothermal coefficient of 1.63 .

Table 2. Weather conditions during of potato vegetation

\begin{tabular}{|c|c|c|c|c|c|c|c|}
\hline \multirow{2}{*}{ Years } & \multicolumn{6}{|c|}{ Months } & \multirow{2}{*}{$\begin{array}{c}\text { April- } \\
\text { September }\end{array}$} \\
\hline & April & May & June & July & August & September & \\
\hline \multicolumn{8}{|c|}{ Air temperature $\left({ }^{\circ} \mathrm{C}\right)$} \\
\hline 2015 & 8.2 & 12.3 & 16.5 & 18.7 & 21.0 & 14.5 & 15.2 \\
\hline 2016 & 9.1 & 15.1 & 18.4 & 19.1 & 18.0 & 14.9 & 15.8 \\
\hline 2017 & 6.9 & 13.9 & 17.8 & 16.9 & 18.4 & 13.9 & 14.6 \\
\hline Multiyear mean 1996-2010 & 8,0 & 13,5 & 17,0 & 19,7 & 18,5 & 13,5 & 15,0 \\
\hline \multicolumn{8}{|c|}{ Rainfall (mm) } \\
\hline 2015 & 30.0 & 100.2 & 43.3 & 62.6 & 11.9 & 47.1 & 295.1 \\
\hline 2016 & 28.7 & 54.8 & 36.9 & 35.2 & 31.7 & 13.6 & 200.9 \\
\hline 2017 & 59.6 & 49.5 & 57.9 & 23.6 & 54.7 & 80.1 & 325.4 \\
\hline Multiyear sum (1996-2010) & 33,6 & 58,3 & 59,6 & 57,5 & 59,9 & 42,3 & 335.4 \\
\hline \multicolumn{8}{|c|}{ Sielianinov's hydrothermic coefficients } \\
\hline 2015 & 1.35 & 2.91 & 0.84 & 1.20 & 0.2 & 1.2 & 1.3 \\
\hline 2016 & 1.08 & 1.47 & 0.72 & 0.64 & 0.62 & 0.28 & 0,8 \\
\hline 2017 & 3.82 & 1.52 & 1.07 & 0.47 & 1.01 & 1.92 & 1.63 \\
\hline
\end{tabular}

Coefficient value [Bac $\mathrm{i}$ in. 1998]:

- up till 0.5 severe drought,

$-0.51-0.69$ drought,

$-0.70-0.99$ poor drought,

$-\geq 1$ fault drought. 
Table 3. Savouriness of potato tubers (scale 1-9)

\begin{tabular}{|c|c|c|c|c|c|c|c|}
\hline \multirow{2}{*}{ Objects } & \multicolumn{3}{|c|}{ Cultivars } & \multicolumn{3}{|c|}{ Years } & \multirow{2}{*}{ Mean } \\
\hline & Honorata & Jelly & Tajfun & 2015 & 2016 & 2017 & \\
\hline 1. Control object & 7.0 & 8.0 & 7.9 & 8.0 & 7.1 & 7.9 & 7.7 \\
\hline 2. Kelpak SL & 8.0 & 8.0 & 7.9 & 7.9 & 8.0 & 7.9 & 7.9 \\
\hline 3. Tytanit & 7.9 & 8.0 & 8.0 & 7.9 & 7.9 & 8.0 & 7.9 \\
\hline 4. GreenOk & 7.9 & 8.0 & 7.9 & 8.0 & 8.0 & 7.9 & 7.9 \\
\hline 5. BrunatneBio Złoto & 7.9 & 7.9 & 7.9 & 7.9 & 7.9 & 7.9 & 7.9 \\
\hline Mean & 7.7 & 8.0 & 7.9 & 7.9 & 7.8 & 7.9 & 7.9 \\
\hline $\begin{array}{l}\mathrm{LSD}_{0.05} \text { for: cultivars I } \\
\text { objects II } \\
\text { years III } \\
\text { interaction: II x III } \\
\text { I x III } \\
\text { I x II } \\
\text { I x II x III }\end{array}$ & & & & & & & $\begin{array}{l}0.4 \\
0.5 \\
0.4 \\
\text { r.n. } \\
\text { r.n. } \\
\text { r.n. } \\
\text { r.n. }\end{array}$ \\
\hline
\end{tabular}

Table 4. Darkening of raw tubers after 10 minutes (scale 1-9)

\begin{tabular}{|c|c|c|c|c|c|c|c|}
\hline \multirow{2}{*}{ Objects } & \multicolumn{3}{|c|}{ Cultivars } & \multicolumn{3}{|c|}{ Years } & \multirow{2}{*}{ Mean } \\
\hline & Honorata & Jelly & Tajfun & 2015 & 2016 & 2017 & \\
\hline $\begin{array}{l}\text { 1. Control object } \\
\text { 2. Kelpak SL } \\
\text { 3. Tytanit } \\
\text { 4. GreenOk } \\
\text { 5. BrunatneBio Złoto }\end{array}$ & $\begin{array}{l}8.9 \\
8.9 \\
8.8 \\
8.8 \\
8.6 \\
\end{array}$ & $\begin{array}{l}8.9 \\
8.8 \\
8.8 \\
8.9 \\
8.9 \\
\end{array}$ & $\begin{array}{l}8.8 \\
8.8 \\
8.8 \\
8.8 \\
8.8 \\
\end{array}$ & $\begin{array}{l}8.9 \\
8.8 \\
8.9 \\
8.8 \\
8.9 \\
\end{array}$ & $\begin{array}{l}8.8 \\
8.8 \\
8.8 \\
8.8 \\
8.8 \\
\end{array}$ & $\begin{array}{l}8.7 \\
8.8 \\
8.7 \\
8.8 \\
8.7 \\
\end{array}$ & $\begin{array}{l}8.8 \\
8.8 \\
8.8 \\
8,8 \\
8.8 \\
\end{array}$ \\
\hline Mean & 8.8 & 8.8 & 8.8 & 8.9 & 8.8 & 8.7 & 8.8 \\
\hline $\begin{array}{l}\mathrm{LSD}_{0.05} \text { for: cultivars I } \\
\text { objects II } \\
\text { years III } \\
\text { interaction: II xIII } \\
\text { I x III } \\
\text { I x II } \\
\text { I x|| x III }\end{array}$ & & & & & & & $\begin{array}{l}0.06 \\
\text { r.n. } \\
0.06 \\
\text { r.n. } \\
0.1 \\
\text { r.n. } \\
\text { r.n. }\end{array}$ \\
\hline
\end{tabular}

The tubers collected in 2015 were less susceptible to darkening. The influence of the weather conditions on this feature was noted by Hamouz et al. [2005]. The demonstrated cooperation of years with varieties proves the different reactions of varieties to the atmospheric conditions of growing seasons. Interactions of the years with the ways bio-stimulator application, varieties with the ways of bio-stimulator application, and years with the experiment factors have not been observed.

Darkening of the pulp of cooked tubers is a very important feature from the point of view of the consumer. Evaluation of darkening of tubers was made after 10 minutes from cooking. Variations, ways of bio-stimulator applications as well as humidity and thermal conditions in the research years have a significant influence on this feature (Table 5). The pulp of the Honorata variety assessed 10 minutes from cooking did not darken at all, while the darkening in the Tajfun variety decreased by 0.1 point - slightly, but significantly, and the Jelly variety - reached the value of 8.7 degrees on a nine-point scale. This was confirmed by the studies of Ciećko et al. [2005], Kołodziejczyk et al. [2005], Sawicka et al. [2006]. While analysing the application of biostimulators, it was observed that significant darkening of tubers - compared to the control object was noted after using the bio-stimulator (objects 2,4 and 5). The differences in assessing the darkening of the pulp ranged from 0.1 to 0.4 points on a 9-point scale (except for object 3 ) in favour of the control object. The weather conditions in the years of conducting the experiment differentiated the analysed feature. The tubers collected in 2017 with optimal rainfall did not darken, and a slight deterioration of this feature was noted in 2015 and 2016, which turned out to be warmer and less humid. Kołodziejczyk [2014] and KrochmalMarczak et al. [2016] in their studies have also found that in hot and dry years the tubers accumulate a lot of starch and are less susceptible to the darkening of the pulp of the cooked tubers. The significance of the "years $\times$ varieties" interaction indicates the need of considering each variety in particular seasons of research. A significant in- 
Table 5. Darkening of cooked tubers after 10 minutes (scale 1-9)

\begin{tabular}{|c|c|c|c|c|c|c|c|}
\hline \multirow{2}{*}{ Objects } & \multicolumn{3}{|c|}{ Cultivars } & \multicolumn{3}{|c|}{ Years } & \multirow{2}{*}{ Mean } \\
\hline & Honorata & Jelly & Tajfun & 2015 & 2016 & 2017 & \\
\hline $\begin{array}{l}\text { 1. Control object } \\
\text { 2. Kelpak SL } \\
\text { 3. Tytanit } \\
\text { 4.GreenOk } \\
\text { 5. BrunatneBio Złoto }\end{array}$ & $\begin{array}{l}9.0 \\
8.9 \\
9.0 \\
8.9 \\
9.0\end{array}$ & $\begin{array}{l}9.0 \\
8.9 \\
8.9 \\
8.9 \\
8.0\end{array}$ & $\begin{array}{l}9.0 \\
8.9 \\
8.9 \\
8.9 \\
8.9\end{array}$ & $\begin{array}{l}9.0 \\
8.9 \\
8.9 \\
8.9 \\
7.8\end{array}$ & $\begin{array}{l}9.0 \\
8.9 \\
9.0 \\
8.9 \\
8.9\end{array}$ & $\begin{array}{l}9.0 \\
9.0 \\
9.0 \\
9.0 \\
9.0\end{array}$ & $\begin{array}{l}9.0 \\
8.9 \\
9.0 \\
8.9 \\
8.6\end{array}$ \\
\hline Mean & 9.0 & 8.7 & 8.9 & 8.7 & 8.9 & 9.0 & 8.9 \\
\hline $\begin{array}{l}\text { LSD }_{0.05} \text { for: cultivars I } \\
\text { objects II } \\
\text { years III } \\
\text { interaction: II xIII } \\
\text { I x III } \\
\text { I x II } \\
\text { I x II x III }\end{array}$ & & & & & & & $\begin{array}{l}0.4 \\
0.5 \\
0.4 \\
0.9 \\
0.7 \\
\text { r.n. } \\
\text { r.n. }\end{array}$ \\
\hline
\end{tabular}

teraction of years with the use of bio-stimulators has also been demonstrated. The cooperation of cultivars with the methods of bio-stimulator application and the years with experimental factors has not been proven.

\section{CONCLUSIONS}

1. The discussed characteristics of consumer value, i.e. tastiness, darkening of the pulp of raw and cooked tubers were independent of the date of bio-stimulator application.

2. Bio-stimulators did not change the tastiness and darkening of the raw tubers pulp, they had a significant effect on the darkening of the cooked tubers.

3. The Honorata variety was characterized by the smallest tendency of the cooked pulp to darken, while the remaining varieties became darker.

\section{REFERENCES}

1. Bac S., Koźmiński C., Rojek M. 1998. Agrometeorologia. PWN. Warszawa, pp. 274 (in Polish).

2. Chotkowski J., Rembeza J. 2006. Consumer preferences and changes in potato consumption. Rocz. Nauk. Stow. Ekon. Rol. i Agrobiznesu, 7(8), 42-49 (in Polish).

3. Ciećko Z., Rogozińska I., Żołnowski A., Wyszkowski M. 2005. The influence of potassium fertilization, at different $\mathrm{N}$ and $\mathrm{P}$ levels, on the culinary features of potato tubers. Biul. IHAR, 237/238, 151-159 (in Polish).

4. Grudzińska M., Zgórska K. 2008b. Effect of sugar content in potato tubers on colour of chips. Żywność. Nauka. Technologia. Jakość, 5(60),
107-115 (in Polish).

5. Gugała M., Zarzecka K., Krasnodębska E., Sikorska A. 2016. Impact of herbicides on consumption characers of potato tubers. J. Ecol. Eng. 17(2), 153-156.

6. Hamouz K., Lachman J., Dvořak P., Pivec V. 2005. The effect of ecological growing on the potatoes yield and quality. Plant Soil Environ., 51(9), 397-402.

7. Kołodziejczyk M., Szmigiel A., 2005. Contents of macronutrients in edible potato tubers depending on the soil complex, variety and fertilization. Fragm. Agron., 22(1), 436-445 (in Polish).

8. Kozak M. 2009. Biostimulator, a good choice. Agrotechnika, 3, 61-62 (in Polish).

9. Krochmal-Marczak B., Sawicka B., KiełtykaDadasiewicz A., Bienia B. 2016. Influence of storage and climatic conditions on the quality tuber flesh potato cultivated in the organic system. Fragm. Agron. 33(2), 44-54 (in Polish).

10. Maciejewski T., Szukała J., Jarosz A. 2007. Influence of biostymulator Asahi SL i Atonik SL on qualitative tubers of potatoes. J. Res. Appl. Agric. Eng., 52(3), 109-112 (in Polish).

11. Nowacki W. 2002. Quality parameters of the prepared potato - genetic and environmental conditions. Zesz. Probl. Post. Nauk Rol., 489, 335-346 (in Polish).

12. Nowacki W. 2006. The share of commercial yield in the total yield of edible potato varieties. Zesz. Probl. Post. Nauk Rol., 511, 429-439 (in Polish).

13. Nowacki W. 2012. Characteristics of the National Register of Potato Varieties. Wyd. IHAR-PIB, Jadwisin, 1-41 (in Polish).

14. Roztropowicz S., Czerko Z., Głuska A., Goliszewski W., Gruczek T., Lis B., Lutomirska B., Nowacki W., Rykaczewska K., Sowa-Niedziałkowska G., Szutkowska M., Wierzejska-Bujakowska A., Zarzyńska K., Zgórska K. 1999. The methodol- 
ogy of observation, measurement and sampling in agronomic experiments with potato. Wyd. IHAR, 1-50 (in Polish).

15. Sawicka B., Kuś J., Barbaś P. 2006. Darkening of potato tuber pulp under the conditions of an ecological and integrated cultivation system. Pam. Puł., 142, 445-457 (in Polish).

16. Słowiński A. 2004. Biostimulators in modern crop cultivation. Nauka i Praktyka, 3(68), 25-26 (in Polish).

17. Stypa I. 2004. Comparison of culinary quality and resistance to viruses of Polish potato varieties accumulated in the gene bank. Mat. Konf. Nauk. Nasiennictwo i ochrona ziemniaka, Kołobrzeg, 83-84 (in Polish).

18. Urbanowicz J. 2010. Response of potato varieties to the applied herbicides. Ziemniak Polski, 2, 31-34 (in Polish).

19. Varis E. 1970. Variation in the quality of table potato and the factors influencing it in Finland. Acta Agralia Fennica, 118(3), 7-99.
20. Wichrowska D., Rogozińska I. 2010. Consumption value of potato tubers depending on the variety and weed control. In: Wojtatowicz M., Kawa-Rygielska J. (Eds.) Jakość i prozdrowotne cechy żywności. Wyd. UP Wrocław, 39-46 (in Polish).

21. Zarzecka K., Gąsiorowska B. 2000. Influence of herbicides on selected qualitative characteristics of edible potato tubers. Żywność. Nauka. Technologia. Jakość, 4(25), 28-36 (in Polish).

22. Zarzecka K., Gąsiorowska B. 2002. The effect of varied care on the consumption value of edible potato. Zesz. Nauk. AP w Siedlcach, Rol., 61, 53-64 (in Polish).

23. Zarzecka K. 2006. Potato cultivation in Poland conditioning the right yield quality. Zesz. Probl. Post. Nauk Rol., 511, 53-72 (in Polish).

24. Zgórska K., Grudzińska M. 2010. Suitability of potato varieties for food processing. Ziemn. Pol. 2, 1-3 (in Polish).

25.Zgórska K., Grudzińska M. 2011. Quality of pasteurized vacuum-packed potatoes. Ziemn. Pol. 2, $1-5$ (in Polish). 